Editorial

\title{
Special Issue: Recombinant Protein Expression in Microorganisms
}

\author{
Trygve Brautaset * and Svein Valla ${ }^{\dagger}$ \\ Department of Biotechnology and Food Sciences, Norwegian University of Science and Technology (NTNU), \\ Sem Selands vei 6/8, 7491 Trondheim, Norway \\ * Correspondence: trygve.brautaset@ntnu.no \\ + Deceased September 2017.
}

Received: 30 August 2019; Accepted: 10 September 2019; Published: 16 September 2019

Microorganisms are widely used in industrial biotechnology as cell factories for the sustainable production of a wide range of compounds and chemicals. For example, virtually any protein from any origin can be efficiently produced using recombinant DNA technology, and bacteria and yeast are, in many instances, the preferred production hosts. Recombinant expression has been a fundamental discipline in molecular biology for decades; yet, we still do not understand some fundamental aspects of this science. Presumably, critical information is hidden in the coding sequences of the genes to be expressed, beyond the well-understood rules concerning rare codons and secondary structure formation at the messenger RNA level. Challenges in recombinant protein expression can occur at any level, including host toxicity, product insolubility and non-functionality, poor translation efficiency, and lack of necessary post-translational modification. Genetic tools and superior hosts have been developed, as well as better software for improved design of expression systems by considering all possible parameters including gene coding sequences, promoters, untranslated leaders regions, transcriptional terminators, mRNA stabilities, protein folding, and translational efficiencies. However, despite of all this progress, recombinant protein expression remains largely a matter of trial and error.

This Special Issue of Microorganisms gathers 14 articles addressing various aspects of recombinant protein production, including genetic tools [1-5], differentiation between soluble proteins versus inclusion bodies and protein kinetics [6-8], fusion proteins [9], recombinant expression in biofilms [10], continuous cultures [11], and high-cell-density cultivation [12]. The articles cover research conducted in several different microbial hosts, including Gram-negative bacterium Escherichia coli [1-3,6-10], Gram-positive bacilli [4,5,11], and yeast [11-14]. Altogether, we think that this Special Issue provides a valuable update on important aspects related to the field recombinant expression in microorganisms.

Acknowledgments: We would like to thank all authors who contributed their excellent papers to this Special Issue. We thank the reviewers for their valuable help in further improving all manuscripts before being published to the highest standard of quality. We are also grateful to all members of the Microorganisms Editorial Office for providing us with this opportunity and for continuous support in managing and organizing this Special Issue.

Conflicts of Interest: The authors declare no conflict of interest.

\section{References}

1. Tagliavia, M.; Nicosia, A. Advanced Strategies for Food-Grade Protein Production: A New E. coli/Lactic Acid Bacteria Shuttle Vector for Improved Cloning and Food-Grade Expression. Microorganisms 2019, 7, 116. [CrossRef] [PubMed]

2. Cheong, D.-E.; Park, S.-Y.; Lim, H.-D.; Kim, G.-J. An Alternative Platform for Protein Expression Using an Innate Whole Expression Module from Metagenomic DNA. Microorganisms 2019, 7, 9. [CrossRef] [PubMed] 
3. Hans, S.; Gimpel, M.; Glauche, F.; Neubauer, P.; Cruz-Bournazou, M.N. Automated Cell Treatment for Competence and Transformation of Escherichia coli in a High-Throughput Quasi-Turbidostat Using Microtiter Plates. Microorganisms 2018, 6, 60. [CrossRef] [PubMed]

4. Larsen, Ø.; Bjerga, G.E.K. Development of Versatile Vectors for Heterologous Expression in Bacillus. Microorganisms 2018, 6, 51. [CrossRef] [PubMed]

5. Drejer, E.B.; Hakvåg, S.; Irla, M.; Brautaset, T. Genetic Tools and Techniques for Recombinant Expression in Thermophilic Bacillaceae. Microorganisms 2018, 6, 42. [CrossRef] [PubMed]

6. Reshetnikov, A.S.; Solntseva, N.P.; Rozova, O.N.; Mustakhimov, I.I.; Trotsenko, Y.A.; Khmelenina, V.N. ATPand Polyphosphate-Dependent Glucokinases from Aerobic Methanotrophs. Microorganisms 2019, 7, 52. [CrossRef] [PubMed]

7. Kopp, J.; Slouka, C.; Strohmer, D.; Kager, J.; Spadiut, O.; Herwig, C. Inclusion Body Bead Size in E. coli Controlled by Physiological Feeding. Microorganisms 2018, 6, 116. [CrossRef]

8. Paraskevopoulou, V.; Falcone, F.H. Polyionic Tags as Enhancers of Protein Solubility in Recombinant Protein Expression. Microorganisms 2018, 6, 47. [CrossRef]

9. Ramamourthy, G.; Arias, M.; Nguyen, L.T.; Ishida, H.; Vogel, H.J. Expression and Purification of Chemokine MIP-3 $\alpha$ (CCL20) through a Calmodulin-Fusion Protein System. Microorganisms 2019, 7, 8. [CrossRef] [PubMed]

10. Soares, A.; Gomes, L.C.; Mergulhão, F.J. Comparing the Recombinant Protein Production Potential of Planktonic and Biofilm Cells. Microorganisms 2018, 6, 48. [CrossRef] [PubMed]

11. Peebo, K.; Neubauer, P. Application of Continuous Culture Methods to Recombinant Protein Production in Microorganisms. Microorganisms 2018, 6, 56. [CrossRef] [PubMed]

12. Vandermies, M.; Fickers, P. Bioreactor-Scale Strategies for the Production of Recombinant Protein in the Yeast Yarrowia lipolytica. Microorganisms 2019, 7, 40. [CrossRef] [PubMed]

13. Carneiro, F.C.; Weber, S.S.; Silva, O.N.; Jacobowski, A.C.; Ramada, M.H.S.; Macedo, M.L.R.; Franco, O.L.; Parachin, N.S. Recombinant Inga laurina Trypsin Inhibitor (ILTI) Production in Komagataella phaffii Confirms Its Potential Anti-Biofilm Effect and Reveals an Anti-Tumoral Activity. Microorganisms 2018, 6, 37. [CrossRef] [PubMed]

14. Vieira Gomes, A.M.; Souza Carmo, T.; Silva Carvalho, L.; Mendonça Bahia, F.; Parachin, N.S. Comparison of Yeasts as Hosts for Recombinant Protein Production. Microorganisms 2018, 6, 38. [CrossRef] [PubMed] 